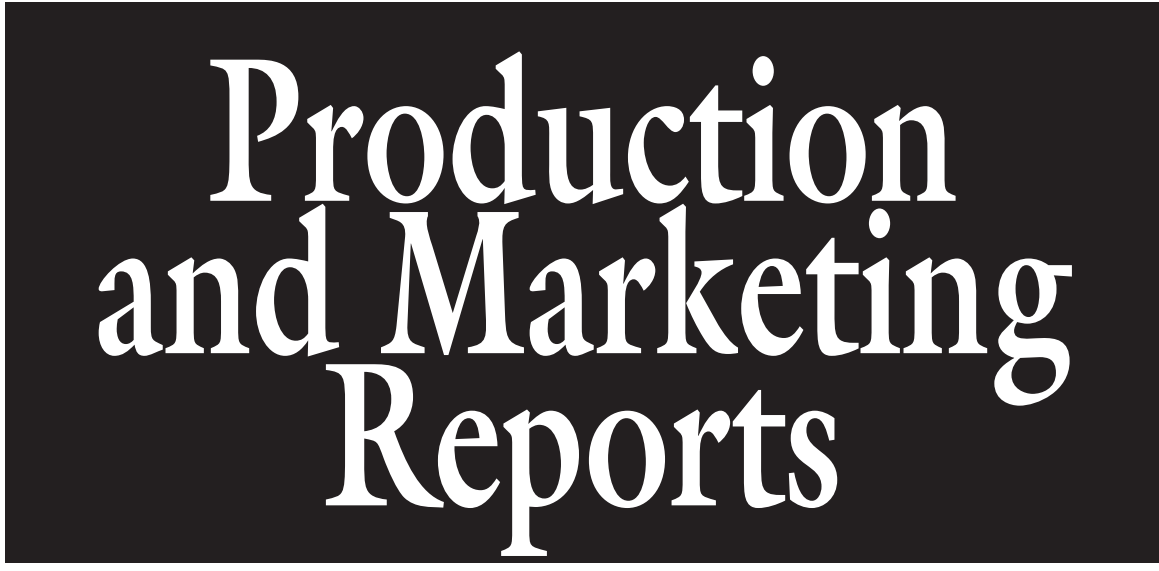

\title{
An Economic Analysis of Two Grafted Tomato Transplant Production Systems in the United States
}

\author{
Cary L. Rivard ${ }^{1,5}$, Olha Sydorovych ${ }^{2,6}$, Suzanne O'Connell ${ }^{3,5}$, \\ Mary M. Peet ${ }^{3,4,7}$, and Frank J. Louws ${ }^{1,7,8}$
}

ADDITIONAL INDEX WORDS. soilborne diseases, organic, IPM, propagation, grafting, rootstock, Solanum lycopersicum

SUMMARY. The grafting of herbaceous vegetables is an emerging development in the United States. This report provides an estimate of the variable costs of grafting within U.S. tomato (Solanum lycopersicum) transplant production systems. Grafted and nongrafted plants were propagated at two commercial farming operations in Ivanhoe, NC (NC) and Strasburg, PA (PA) and the farm in NC produced certified organic transplants. Detailed economic production sequences were generated for each site, and grafted and nongrafted transplant production costs were $\$ 0.59$ and $\$ 0.13$ in NC, and \$1.25 and \$0.51 in PA, respectively. Direct costs associated with grafting (e.g., grafting labor, clips, chamber, etc.) accounted for $37 \%$ to $38 \%$ of the added cost of grafting, and grafting labor was $11.1 \%$ to $14.4 \%$ of the cost of grafted transplant production. Seed costs represented $52 \%$ and $33 \%$ of the added cost of grafting at the two sites, and indirect costs (e.g., soil, trays, and heating) accounted for $10 \%$ and $30 \%$ of the added cost of grafting. Our findings suggest that under current seed prices and with similar production practices, the feasibility of grafting in the United States is not disproportionately affected by domestic labor costs. Additionally, the economic models presented in this report identify the cost of production at various transplant stages, and provide a valuable tool for growers interested in grafted tomato transplant production and utilization.

$\mathrm{R}$ ecently, grafting has gained increased attention for U.S. toet al., 2008; Kubota et al., 2008). Field trials in the southeastern U.S. showed that resistant rootstocks can be used to manage site-specific soilborne diseases such as bacterial wilt (Ralstonia solanacearum) (Freeman et al., 2009; Rivard et al., 2008a; Rivard and Louws, 2008), Fusarium wilt (F. oxysporum $\mathrm{f}$. sp. lycopersici) (Rivard and Louws, 2008), southern blight (Sclerotium rolfsii) (Rivard et al., in press), and root-knot nematodes (Meloidogyne spp.) (Kokalis-Burelle et al., 2008; Rivard et al., in press). Furthermore, grafting has been proposed worldwide as a component in integrated pest management programs that are not dependent on the soil fumigant methyl bromide (Besri, 2003, 2007; Minuto and Causarano, 2008). Methyl bromide has been an integral part of tomato production in the United States, but is being phased out according to the Montreal Protocol (Martin, 2003; Noling and Becker, 1994; Sydorovych et al., 2008).

With the exception of the hydroponic greenhouse industry, few tomato growers in the United States use grafted transplants for fruit production (Kubota et al., 2008). There are two primary assumptions used to justify the lack of grafting in the United States. The first is that U.S. labor costs are too high for manual grafting to be a feasible component of transplant production. Second, U.S. tomato fruit production systems may not generate the necessary per plant revenue to use grafted plants in a profitable way. Due to the recent regulatory issues associated with soil fumigants and the shift toward more intensive production systems among the organic sector, tomato growers are interested in producing grafted plants grown on the farm or purchased from specialized propagation facilities. Tomato grafting may provide an emerging niche for commercial propagators wishing to capture retail or wholesale markets, including organic and heirloom tomato plant sales (Rivard and Louws, 2006).

The most common tomato grafting technique for commercial propagation worldwide is tube grafting (Oda, 1999; Rivard and Louws, 2006). This technique is highly effective and can be performed when the plants are very small, thereby increasing throughput (Lee, 2003). The tube grafting procedure is relatively quick, and manual grafting rates range from 300 to 500 plants $/ \mathrm{h}$ per worker (Kubota et al., 2008).

Even with the advent of tube grafting, legitimate concerns in the United States have been raised regarding the cost of labor required for the grafting procedure (Kubota et al.,

\begin{tabular}{llll}
\hline $\begin{array}{l}\text { Units } \\
\begin{array}{l}\text { To convert U.S. to SI, } \\
\text { multiply by }\end{array}\end{array}$ & U.S. unit & SI unit & $\begin{array}{l}\text { To convert SI to U.S., } \\
\text { multiply by }\end{array}$ \\
\hline 0.4047 & acre(s) & ha & 2.4711 \\
0.0929 & $\mathrm{ft}^{2}$ & $\mathrm{~m}^{2}$ & 10.7639 \\
3.7854 & gal & $\mathrm{L}$ & 0.2642 \\
2.54 & inch(es) & $\mathrm{cm}$ & 0.3937 \\
25.4 & inch(es) & $\mathrm{mm}$ & 0.0394
\end{tabular}


2008). Grafting robots have been proposed as one alternative to reduce the cost of grafting labor worldwide (Lee, 2003), but their current use for tomato is relatively low (Kubota et al., 2008).

In addition to manual grafting labor, grafted production requires other direct costs such as grafting supplies and healing chamber materials (Rivard and Louws, 2006). Additionally, rootstock seed must be purchased and excess seed must be planted (oversowing) to account for less than $100 \%$ grafting success. Grafting also increases variable costs indirectly as it adds about $7 \mathrm{~d}$ onto the transplant production cycle and requires a complementary seedling crop of scion material before grafting (Rivard and Louws, 2006). This increases materials, labor, and heating costs before grafting of the rootstock and scion seedling crops.

Although interest in grafting is high among U.S. growers and researchers, little work has been done to determine the economic costs and potential benefits of grafted transplant production for retail and commercial sale, or on-farm use. Furthermore, the first step in development of tomato production budgets with and without the use of grafting is to determine the cost of comparable grafted and nongrafted plants. Therefore, it is critical to identify the specific cost or range of costs that growers may experience as

\footnotetext{
The mention of a trademark, proprietary product, or vendor does not constitute a guarantee or warranty of the product and does not imply its approval to the exclusion of other products or vendors that also may be suitable.

We would sincerely like to thank Stefan Hartmann (Black River Organic Farm), Chris Powell (Good Harvest Farms), Steve Groff (Cedar Meadow Farm), Dr. Michael Orzolek (Pennsylvania State University), and Penn State Extension for cooperation on this project. Special thanks to Noel Mooney, Kaitlin Dye, and Dana Groff. Funding provided by the Organic Farming Research Foundation, Northeast Region SARE FNE09-658, Southern Region SARE LS06-193 and GS07-060, and USDA-NIFA 2007-51106-03794.

${ }^{1}$ Department of Plant Pathology, North Carolina State University, Raleigh, NC 27695

${ }^{2}$ Department of Agricultural and Resource Economics, North Carolina State University, Raleigh, NC 27695

${ }^{3}$ Department of Horticultural Science, North Carolina State University, Raleigh, NC 27695

${ }^{4}$ Current address: U.S. Department of Agriculture, National Institute of Food and Agriculture, Washington, DC 20250.

${ }^{5}$ Graduate Research Assistant.

${ }^{6}$ Researcher.

${ }^{7}$ Professor.
}

${ }^{8}$ Corresponding author. E-mail: frank_louws@ncsu.edu. they produce grafted plants or implement grafting into their farming operations.

Published reports on the cost of grafted tomato transplants are rare. In Morocco, nongrafted and grafted tomato plants were produced for $\$ 0.19$ and $\$ 0.38$, respectively (Besri, 2003). In a recent review article, the use of grafted plants was estimated to add $\$ 0.60$ to $\$ 0.90$ per transplant (excluding seed costs) for U.S. production (Kubota et al., 2008). Currently, about 40 million grafted transplants are imported into the United States for large greenhouse operations (Kubota et al., 2008), and the cost of the Canadian transplants is $\$ 2.00$ per plant in addition to seed costs (C. Powell, personal communication). A preliminary report from North Carolina suggested that the utilization of grafted plants would increase fruit production costs by $\$ 2275 /$ acre (O'Connell et al., 2009b), and a more in-depth description of transplant production methods as well as the subsequent analysis of the variable costs of production is provided here.

To identify the relevance of grafting for domestic tomato production, it is essential to determine the cost of grafted transplants propagated in the United States. Therefore, the goal of this study was to identify growers in the United States who successfully produced grafted tomato transplants and report their production models and any corresponding variable costs associated with grafted and nongrafted propagation; to dissect the variable costs of grafted production and examine grafting labor and other key components that could be important considerations for propagation in the United States; and to determine if tomato grafting can provide an economic benefit to local propagation facilities by adding value to tomato transplant production.

\section{Materials and methods}

Grafted and nongrafted tomato plants were produced at Black River Organic Farm (Ivanhoe, NC) and Good Harvest Farms (Strasburg, PA). Rootstock and scion cultivars were chosen based on the needs of each individual farm and market with grafting and healing chamber management conducted by farm personnel (Rivard and Louws, 2006). Three batches of grafted plants were produced throughout the spring at each site. Detailed transplant production sequences were formulated independently based on the experiences of each on-farm collaborator, and the variable costs associated with grafted and nongrafted transplant production were calculated. The specific transplant production methods varied at each location and are described below.

ON-FARM Grafting: NORTH Carolina site. In 2008, $\approx 1000$ certified organic grafted transplants were produced at Black River Organic Farm to determine the feasibility and utility of grafting for a small-scale organic farming operation (O'Connell et al., 2009b). Transplants were produced in three batches of about 350 plants (three to five true leaf stage). 'Celebrity' (Harris Seeds, Rochester, NY) was grafted as scion onto 'RST04-105-T' (DP Seeds, Yuma, AZ) rootstock. In this case, the grower was producing grafted plants solely for use on the farm and transplants were produced in a greenhouse that was used in the late spring and summer for vegetable production (Fig. $\mathrm{IA}$ and $\mathrm{lB}$ ). Therefore, heating costs were low and no mark-up was included in the final production cost. Grafted transplants were produced in accordance with organic certification. Organic fertilizers were used, potting media was listed by the Organic Materials Review Institute (OMRI), and rootstock and scion seed were untreated.

Rootstock and scion seeds were germinated in 512-cell plug trays within a small, heated germination chamber. After $7 \mathrm{~d}$, rootstock and scion seedlings (one true leaf stage) were transplanted into 50-cell trays $(4.5 \mathrm{~cm}$ cell diameter) and allowed to grow for $14 \mathrm{~d}$. Grafting was carried out when the plants had two to three true leaves. Once grafting had occurred, the plants were placed into a healing chamber $(30 \times 48$ inches $)$ constructed from rebar, concrete blocks, plastic sheeting, and a coolmist vaporizer (Fig. lA). The vaporizers were refilled twice daily and the chamber was managed for optimum healing conditions (Rivard and Louws, 2006). After the plants spent $7 \mathrm{~d}$ in the healing chamber, they were moved back into the greenhouse environment for $7 \mathrm{~d}$ to re-acclimate and finish healing before field planting (three to five true leaf stage). 
ON-FARM GRAFTING: PENNSYLVANIA SITE. In $2009, \approx 10,000$ grafted transplants were produced at Good Harvest Farms to investigate the use of grafted tomato plants for high tunnel tomato production at Cedar Meadow Farm (Holtwood, PA) (Groff, 2009a, 2009b). Good Harvest Farms houses a 40,000 $\mathrm{ft}^{2}$ transplant production facility for local commercial and retail ornamental and vegetable plant sales. Grafted tomato transplants were produced in three batches of about 3300 grafted plants. 'BHN 589' (BHN Seed, Immokalee, FL) was grafted as scion onto 'Maxifort' (De Ruiter Seeds, Bergschenhoek, The Netherlands) rootstock. In this case, the client was using decreased planting densities for fruit production and requested that the plants were pruned into a "twin-leader" and grown in larger 18 -cell trays $[8 \times 8 \mathrm{~cm}$ cell (Fig. 1D)]. Because the grafted plants at the PA location were being sold to a local tomato grower, a wholesale mark-up $(50 \%)$ was included at the end of the economic production sequence.

Rootstock and scion seedlings were germinated by a local custom plug producer (York, PA) in 288-cell trays and were allowed to grow for $3 \mathrm{~d}$ upon arrival at Good Harvest Farms. The seedlings ( 1 true leaf stage) were transplanted into 50-cell trays and were allowed to grow for $21 \mathrm{~d}$ in the greenhouse before being grafted (two to three true leaf stage). Once grafted, the plants were moved into a healing chamber for $7 \mathrm{~d}$. The healing chamber was built on top of an "ebband-flow" greenhouse bench using wire hoops, plastic sheeting, shade fabric, and four cool-mist vaporizers (Fig. 1C). Similar to the other location, the grafted plants were monitored twice daily, and light and humidity levels were maintained in accordance with current grafting protocols (Rivard and Louws, 2006). Once the plants (three to five leaf stage) were moved back into the greenhouse, they were transplanted into an 18-cell tray, pruned, and grown for $14 \mathrm{~d}$ before being hardened off in an unheated greenhouse for $7 \mathrm{~d}$ before sale (Fig. 1D). At the time of sale, the plants had two leaders, and each leader had three to five true leaves (6-10 true leaf stage).

Methodology of economic ANALYSIS. A detailed grafted and nongrafted production sequence was generated for each location based on the data and experiences gained at each facility. Line items included all variable costs associated with grafted and nongrafted transplant production, and were specific to each location. Material prices used for transplant production and grafting are shown in Tables 1 and 2, and were used during the calculation of the variable production costs. Summaries of the variable per plant production costs are shown in Fig. $2 \mathrm{~A}$ and $2 \mathrm{~B}$ with the accumulation of variable production costs plotted on the $\mathrm{y}$-axis. The discrete and continuous costs of each production stage are illustrated in the figures by the height of the rectangles and the slopes of the corresponding triangles, respectively (see Table 3 ). The transplant production sequence was plotted along the $\mathrm{x}$-axis to illustrate the costs of specific transplant stages. A categorical summary of the variable costs for each location is shown in Tables 4 and 5 , and the proportional cost of categorical line items in relation to the total cost of transplant production is shown in Table 6 (ITEM $\div$ TOTAL). The distribution of the added costs of grafting is shown in Fig. 3, and this approach describes the proportion of each factor (e.g., seed costs) in relation to the added cost of grafting [(SEEDgraft - SEEDnon $) \div$ (TOTALgraft TOTALnon)].

Assumptions of THE ECONOMIC MODEL. The production sequences did not consider fixed costs such as land value and initial costs of greenhouse structure. The objectives of the study were to determine the variable costs of grafted versus nongrafted transplant propagation and to ascertain any economic costs and benefits of integrating grafting in an existing tomato propagation facility.

Two base wage rates were used in the development of the budgets. It was assumed that $\$ 10.08 / \mathrm{h}$ was paid to hired labor and $\$ 14.00 / \mathrm{h}$ was paid to skilled/managerial labor at both locations (U.S. Department of Agriculture, 2009), but rates of $\$ 11.79 / \mathrm{h}$ to $\$ 16.39 / \mathrm{h}$ were used to account for workers' compensation, unemployment, FICA taxes, and other indirect costs in addition to the base wage rate. Reusable materials such as the healing chamber and cool-mist vaporizers were depreciated according to the number of batches of grafted plants that could be produced
(Tables 1 and 2). Similarly, variable costs incurred for healing chamber materials and construction correspond to the size of the batches that were grafted at each location (Tables 1 and 2).

Grafting clips were not reused and rootstock and scion seed costs were based on current market prices at the time of budget development. All plant and seed numbers were calculated to reflect plant and seed loss that may occur during germination, propagation, and grafting. Rootstock and scion seed were oversown by $20 \%$ to account for germination rate and uniformity, and grafting success was assumed to be $90 \%$, consistent with grower experience. Grafting speed was 200 and 100 plants per person per hour at the NC and PA locations, respectively, and grafting labor was paid $\$ 10.08 / \mathrm{h}$ in $\mathrm{NC}$ and $\$ 14.00 / \mathrm{h}$ in PA.

At the PA location, grafted plants were sold to a local tomato grower. However, no market had been established for locally raised grafted transplants, thus the imposed price was based on typical wholesale mark-up for commercial vegetable plant sales at Good Harvest Farms. The collaborating propagator indicated that a $50 \%$ mark-up was their typical "goal" and this value was used to calculate a selling price.

\section{Results and discussion}

COST OF NONGRAFTED TRANSPLANT PRODUCTION. The cost of nongrafted plants (TOTALnon) at the NC and PA locations was $\$ 0.13$ and $\$ 0.51$ per plant, respectively (Fig. $2 \mathrm{~A}$ and $2 \mathrm{~B})$. At both locations, material costs (excluding seeds) comprised the highest expense, and ranged from $44.0 \%$ to $48.8 \%$ (Table 6 ). During production of nongrafted plants, labor costs ranged from $28.8 \%$ to $36.9 \%$ (Table 6). Although nongrafted seed prices were higher at the PA location than in NC (Tables 1 and 2), the overall seed costs were $14.3 \%$ of the total transplant costs in PA compared with $27.1 \%$ in NC (Table 6). Labor and materials added $\$ 0.10$ per transplant at the $\mathrm{NC}$ site and $\$ 0.42$ per plant on top of initial seed costs (Fig. $2 \mathrm{~A}$ and $2 \mathrm{~B}$ ). Continuous costs (Table 3 ) accumulated more quickly in the PA production sequence (Fig. 2B) compared with the NC site (Fig. 2A) and this is illustrated by the increased slope of the triangles on the 

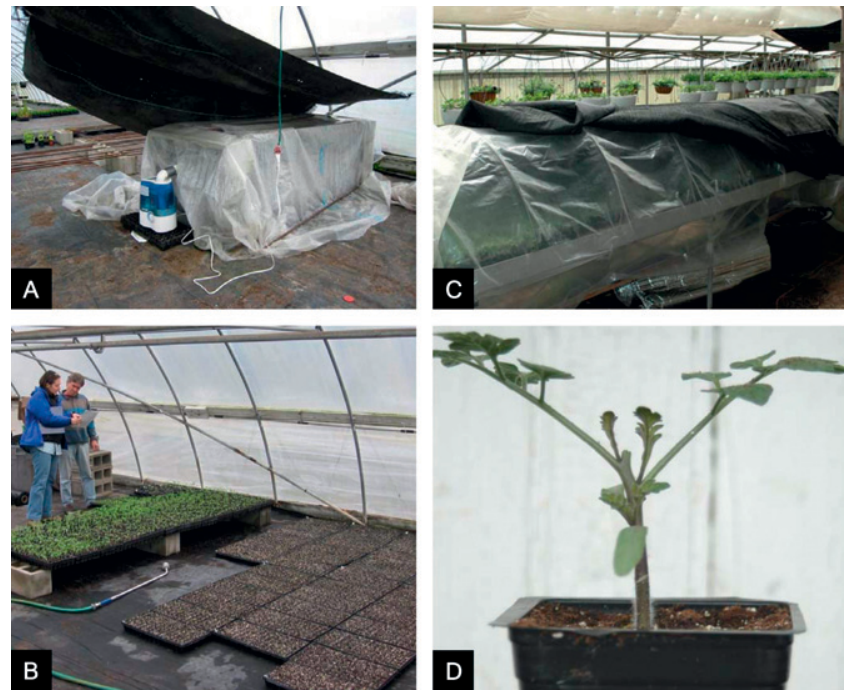

Fig. 1. Healing chambers used for grafted tomato production at (A) Black River Organic Farm, Ivanhoe, NC, and (C) Good Harvest Farms, Strasburg, PA. (B) Seedling propagation at Black River Organic Farm. (D) "Twinleader" transplant 2 weeks before sale/planting.

A

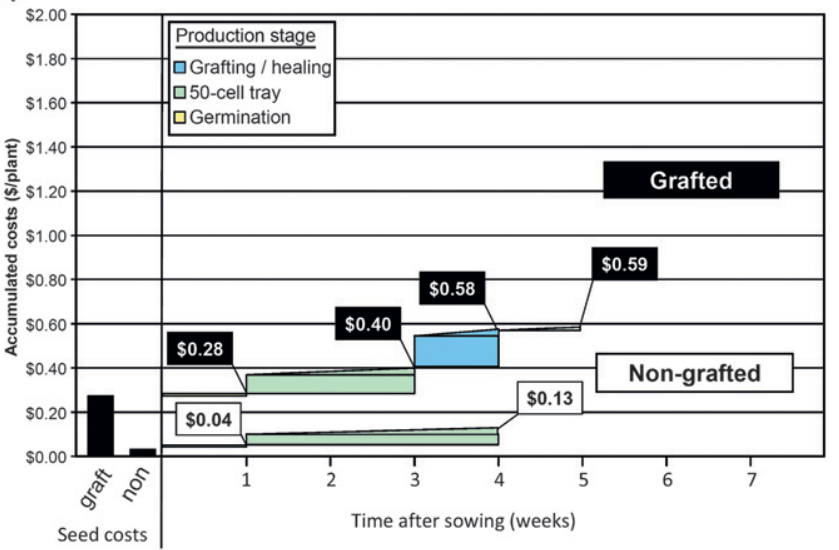

B

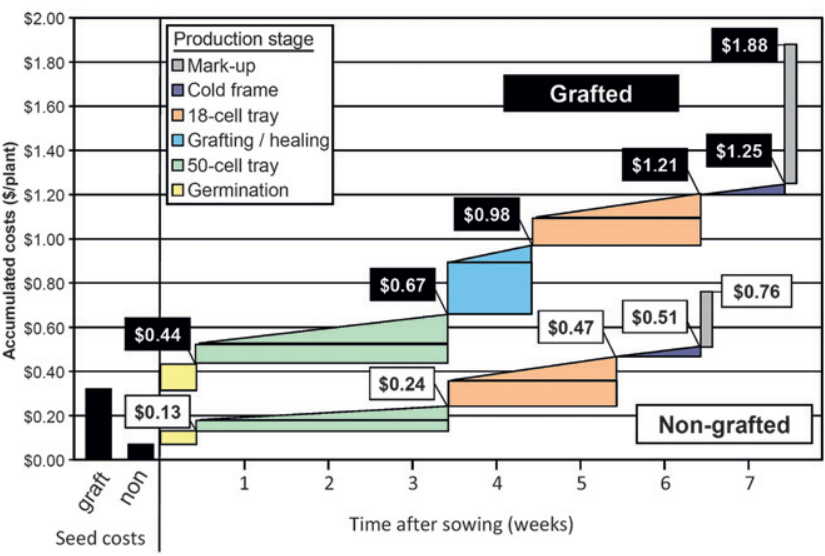

Fig. 2. Economic timeline of a grafted and nongrafted tomato transplants at (A) Black River Organic Farm, Ivanhoe, NC, and (B) Good Harvest Farms, Strasburg, PA. Rectangles and triangles scaled to represent discrete (e.g., transplanting labor, materials, grafting labor, clips, etc.) and continuous (e.g., overhead, daily watering labor, fertilizer, etc.) expenses, respectively.

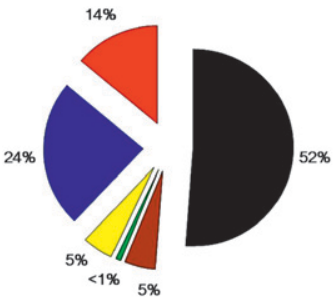

NC location

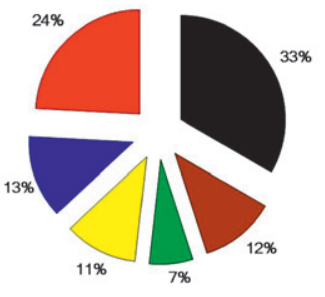

PA location
- Seed - Misc. materials - Heating $\square$ Transplant labor - Chamber / clips $\square$ Grafting labor

Fig. 3. Distribution of the added cost of grafting at the Ivanhoe, NC (NC) and Strasburg, PA (PA) locations. Additional per plant cost of grafting was \$0.46 in NC and $\$ 0.74$ in PA. The distribution represents the proportion of each factor in relation to the added cost of grafting [e.g., seed costs $=($ SEEDgraft - SEEDnon $) \div($ TOTALgraft TOTALnon)].
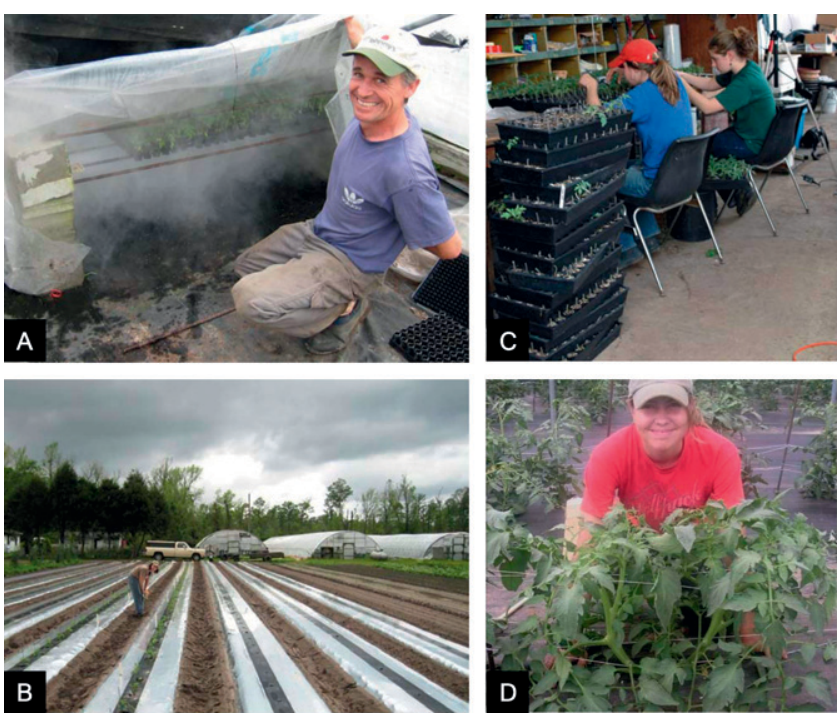

Fig. 4. Newly grafted plants (A) and organic tomato production area adjacent to propagation greenhouses $(B)$ at Black River Organic Farm, Ivanhoe, NC. (C) Manual grafting at Good Harvest Farms, Strasburg, PA. (D) "Twinleader" transplants in production at Cedar Meadow Farm, Holtwood, PA (Photo courtesy: Steve Groff).

economic timelines. The PA facility used hourly and skilled labor during daily transplant care and watering and heating costs were higher than in NC (Tables 4 and 5 ).

Across the two locations, there was a distinct difference in plant size that was required for use/sale. The transplant production methods required to produce the transplants in NC (three to five true leaf stage) compared with the ones in PA (twin-leader, six to 10 true leaf stage) had a strong influence on variable costs. At the PA site, plants were grown for 2.5 weeks longer than in $\mathrm{NC}$, and were transplanted into an 18-cell tray 3 weeks before sale (Fig. $2 \mathrm{~A}$ and $2 \mathrm{~B}$ ). This production stage 
Table 1. Prices of materials for the production of grafted and nongrafted tomatoes at Black River Organic Farm, Ivanhoe, NC. ${ }^{\mathrm{z}}$

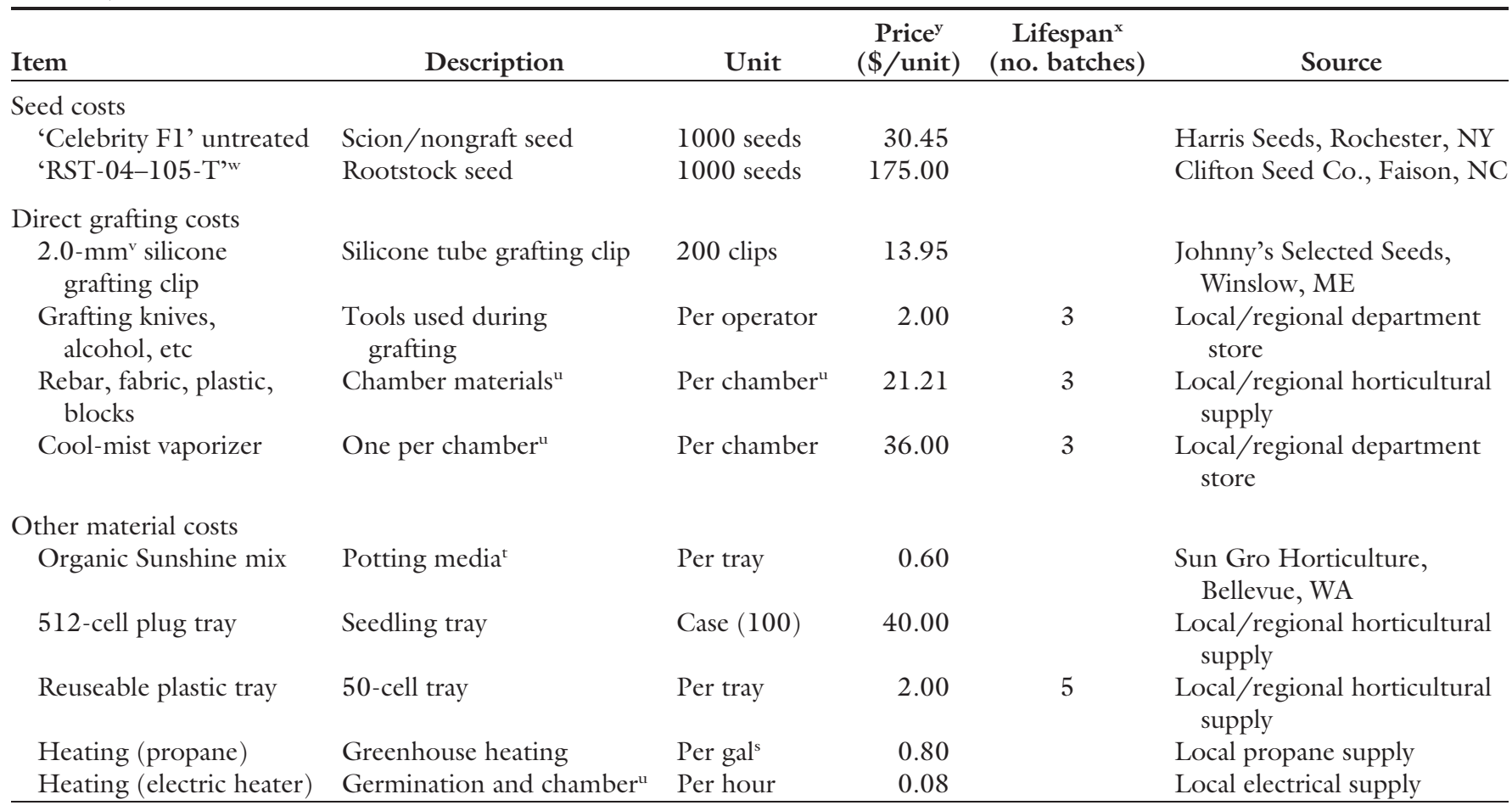

${ }^{\mathrm{z}}$ Adapted from O'Connell et al. (2009b).

y Based on prices during budget development in Fall 2009

${ }^{\mathrm{x}}$ Lifespan refers to the number of batches of grafted transplants that were used to depreciate reuseable items in the production sequence. Three batches were produced during Spring 2008.

wDP Seeds, Yuma, AZ.

${ }^{v} 1 \mathrm{~mm}=0.0394$ inch.

"Once grafted, tomato transplants were placed in a healing chamber that holds 400 plants for $7 \mathrm{~d}$.

tOrganic fertilizers (e.g., bone meal, feather meal, etc.) were incorporated into potting media.

s $\$ 1.00 / \mathrm{gal}=\$ 0.2642 / \mathrm{L}$.

added transplanting labor and materials and also substantial heating costs as each plant in an 18-cell tray required about three times as much space in the greenhouse as one in a 50-cell tray. The 18 -cell production stage in PA added $\$ 0.23$ per plant (Fig. 2B), which accounts for the majority of the per plant difference between the cost of nongrafted production at the two locations.

AdDitional COSTS OF GRAFTED TRANPLANT PRODUCTION. The additional cost of producing a grafted plant (TOTALgraft - TOTALnon) was $\$ 0.46$ and $\$ 0.74$ per plant at the NC and PA sites, respectively (Table 4 and 5 ). These costs reflect additional rootstock and scion seed costs, the direct costs of grafting (e.g., grafting labor, clips, healing chamber, etc.), and the indirect costs associated with growing a rootstock and scion crop before grafting. At the NC location, finished transplants had three to five true leaves, and additional seed costs $(52 \%)$, grafting materials $(24 \%)$, and grafting labor $(14 \%)$ were the three most important variable expenses related to grafted transplant production (Fig. 3). At the PA location, finished transplants had six to 10 true leaves, and seed costs $(33 \%)$, combined indirect costs $(30 \%)$, and grafting labor (24\%) were the three most important variable expenses in relation to grafting (Fig. 3).

SEed COSTS AssSociated WITH GRAFTING. At both locations, the additional seed costs required for grafted transplant production were the most important single component in relation to the added costs of grafting (Fig. 3). The proportional seed costs of grafted plants accounted for $46.5 \%$ and $25.6 \%$ of the total cost of production at the $\mathrm{NC}$ and $\mathrm{PA}$ facilities, respectively, and were nearly double those of nongrafted plants at both locations (Table 6 ). The rootstock seed used in this study is relatively expensive $(\$ 0.17-\$ 0.20$ per seed) compared with the prices of complementary scion seed or seed for nongrafts (\$0.03-\$0.07 per seed). Currently, very few rootstock cultivars are available to U.S. growers, and the cost of rootstock seed could go down if a market develops in the United States. Overseeding and the assumed $90 \%$ grafting success had negligible impacts on scion seed costs but further amplified the increased price of rootstock (Tables 4 and 5 ).

Direct COSTS ASSOCIATED WITH GRAFTING. The direct costs of grafting include line items that were added into the production sequence of the grafted plants, but were not listed in the nongrafted budget. These costs comprised $37 \%$ to $38 \%$ of the additional costs of grafting at the two locations (Fig. 3). The "grafting/ healing stage" added $\$ 0.18$ and $\$ 0.31$ per plant at the $\mathrm{NC}$ and $\mathrm{PA}$ sites, respectively (Fig. $2 \mathrm{~A}$ and $2 \mathrm{~B}$ ).

Grafting labor accounted for $14 \%$ to $24 \%$ of the added cost of grafting (Fig. 3) and represented $11.1 \%$ to $14.4 \%$ of the total cost of production (Table 6). Per plant labor costs are dependent on grafting speed, success, and the hourly wage of trained employees. In PA, a more conservative 
Table 2. Prices of materials for the production of grafted and nongrafted tomatoes at Good Harvest Farms, Strasburg, PA.

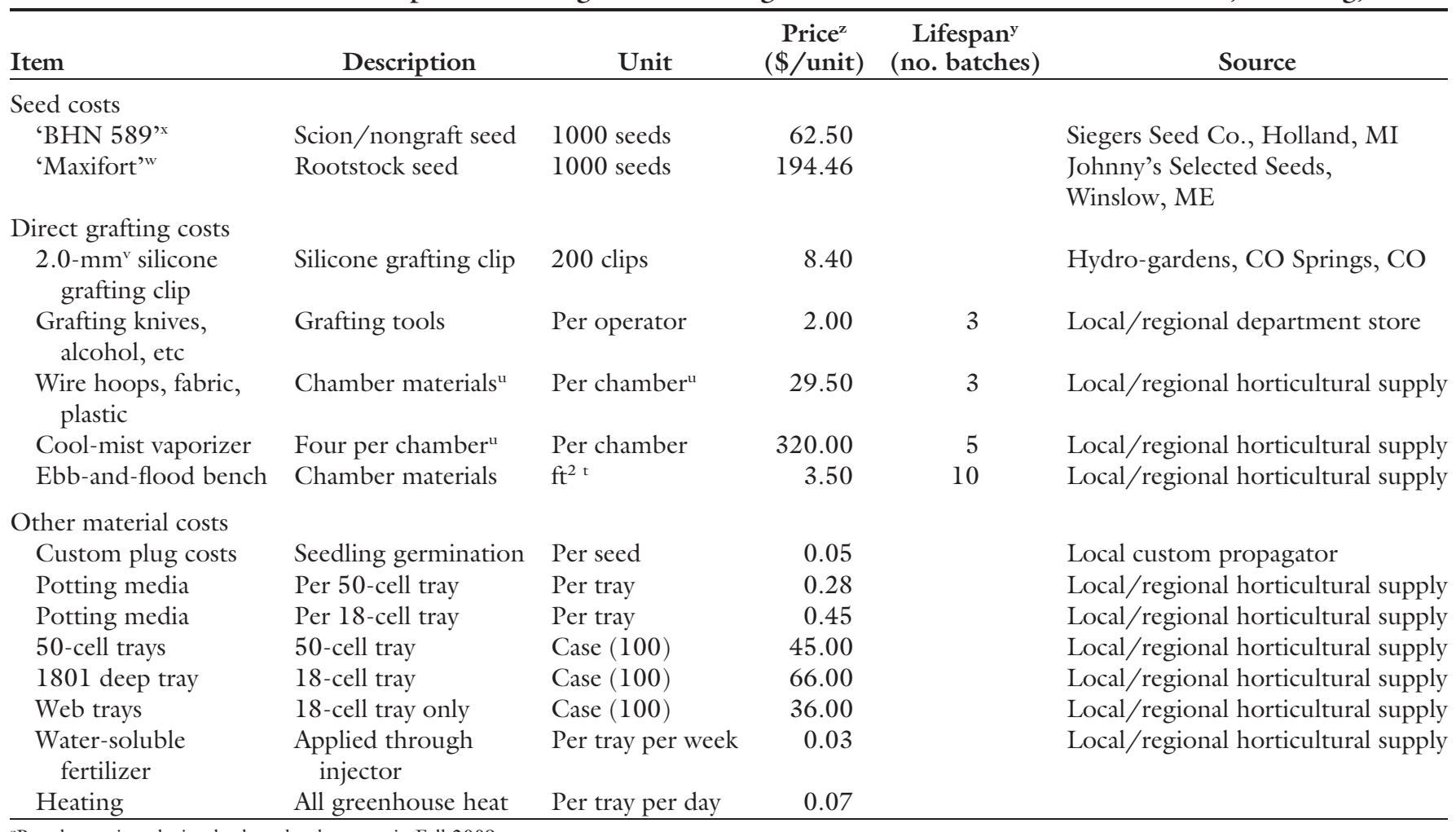

${ }^{2}$ Based on prices during budget development in Fall 2009.

'Lifespan refers to the number of batches of grafted transplants that were used to depreciate reuseable items in the production sequence. Three batches were produced during Spring 2009.

${ }^{x}$ BHN Seed, Immokalee, FL.

"De Ruiter Seeds, Bergschenhoek, The Netherlands.

${ }^{v} 1 \mathrm{~mm}=0.0394$ inch.

"Once grafted, tomato transplants were placed in a healing chamber that holds 3300 plants for $7 \mathrm{~d}$.

t $\$ 1.00 / \mathrm{ft}^{2}=\$ 10.7639 / \mathrm{m}^{2}$.

Table 3. List of variable costs during grafted and nongrafted tomato transplant production $^{\mathrm{z}}$.

\begin{tabular}{ll}
\hline Discrete $^{\mathrm{y}}$ & \multicolumn{1}{c}{ Continuous $^{\mathbf{x}}$} \\
\hline Plug costs (PA only) & Daily watering \\
Potting mix & Heating costs \\
Seedling trays & Transplant care/scouting \\
Transplanting labor & Weekly fertilizer (PA only) \\
Grafting facility & Healing chamber costs \\
Grafting equipment & Humidifier costs \\
Grafting clips & Healing chamber care \\
Grafting labor &
\end{tabular}

${ }^{z}$ Variable costs were itemized in production sequences from two commercial farms in North Carolina and Pennsylvania (PA). Discrete and continuous expense categories were used for the development of Figs. $2 \mathrm{~A}$ and B.

yiscrete variable costs include line items that add to production costs as individual items or events.

xContinuous variable costs include line items that accumulate over time during transplant production.

speed (100 plants/h) combined with the higher pay rate $(\$ 14 / \mathrm{h})$ increased the per plant costs of manual grafting compared with the NC study. It is estimated that an experienced worker could graft $>250$ plants $/ \mathrm{h}$ with $>95 \%$ success (C.L. Rivard and F.J. Louws, unpublished data), and others have reported manual grafting rates from 300 to 500 plants $/ \mathrm{h}$ for tube grafting (Kubota et al., 2008).
Grafting clips and healing chamber materials accounted for $24 \%$ and $13 \%$ of the added cost of grafting at the NC and PA sites, respectively (Fig. 3). The price of the silicone grafting clips ranged from $\$ 0.04$ to $\$ 0.07$ per clip (Tables 1 and 2). Grafting clips may be collected, sterilized, and re-used (Rivard and Louws, 2006), but the cost effectiveness of this practice is unknown.
Healing chamber materials and labor represented a relatively small portion $(3.7 \%-5.1 \%)$ of the total cost of grafted transplant production (Table 6). Cool-mist vaporizers were used to increase the humidity within the healing chambers (Figs. $1 \mathrm{~A}$ and $4 \mathrm{~A}$ ), and although they represent a relatively insignificant source of material costs (Table 6), these devices may not be needed in larger healing chambers.

INDIRECT COSTS ASSOCIATED WITH GRAFTING. Indirect costs associated with grafting represent line items that were increased (per plant) in the grafted production sequence compared with the nongrafted plants. Indirect costs such as additional soil, trays, labor, and heating were $46 \%$ and $51 \%$ higher during the production of the grafted plants in NC and PA, respectively (Tables 4 and 5 ). These costs were particularly important in the PA study, and the combined indirect costs (miscellaneous materials, heating, transplant labor) accounted for $10 \%$ and $30 \%$ of the added costs of grafting in $\mathrm{NC}$ and $\mathrm{PA}$, 
Table 4. Variable costs of tomato transplants at Black River Organic Farm, Ivanhoe, $\mathrm{NC}^{\mathrm{z}}$

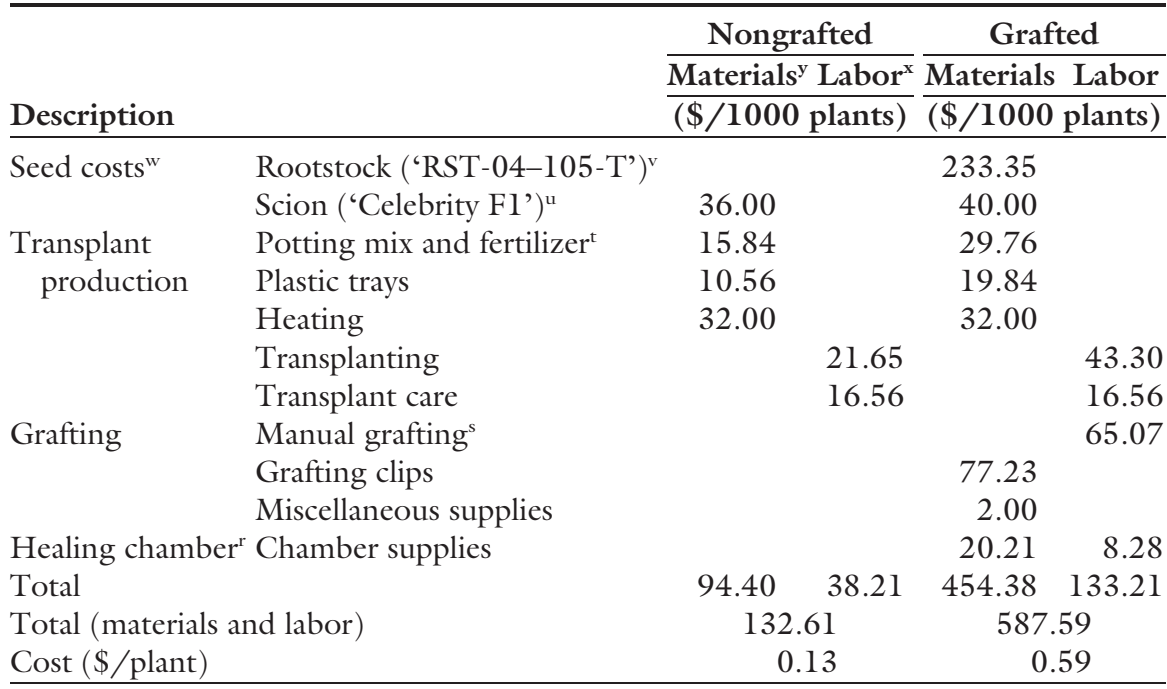

${ }^{2}$ Adapted from O'Connell et al. (2009b).

'Based on prices during budget development in Fall 2009.

${ }^{x}$ Based on average hourly agricultural wages (U.S. Department of Agriculture, 2009).

wSeed costs were calculated to reflect the total cost required for $20 \%$ oversowing and $90 \%$ grafting success (where applicable).

'Interspecific rootstock cultivar (DP Seeds, Yuma, AZ).

"Determinate fresh-market variety (Harris Seeds, Rochester, NY).

${ }^{t} B o n e$ meal, feather meal, and other organic amendments were incorporated into potting mix.

Grafting rate was 200 plants/worker/h and grafting wage was $\$ 10.08 / \mathrm{h}$. Grafting success rate was $90 \%$.

${ }^{\mathrm{r}}$ Once grafted, tomato transplants were placed in a healing chamber that holds 400 plants for $7 \mathrm{~d}$.

Table 5. Variable costs of tomato transplants at Good Harvest Farms, Strasburg, PA.

\begin{tabular}{|c|c|c|c|c|c|}
\hline \multirow{3}{*}{ Description } & & \multicolumn{2}{|c|}{ Nongrafted } & \multicolumn{2}{|c|}{ Grafted } \\
\hline & & Materials $^{\mathrm{z}}$ & Labor $^{y}$ & Materials $^{\mathrm{z}}$ & Labor $^{\mathrm{y}}$ \\
\hline & & $(\$ / 1000$ & plants) & $(\$ / 1000$ & plants) \\
\hline \multirow{2}{*}{ Seed costs ${ }^{x}$} & Rootstock ('Maxifort')w & & & 242.69 & \\
\hline & Scion $\left({ }^{\prime B H N ~ 589 ')^{v}}\right.$ & 72.92 & & 78.13 & \\
\hline \multirow{6}{*}{$\begin{array}{l}\text { Transplant } \\
\text { production }\end{array}$} & Custom plug costs ${ }^{\mathrm{u}}$ & 57.60 & 1.38 & 124.80 & 2.95 \\
\hline & Potting mix & 30.65 & & 37.37 & \\
\hline & Plastic trays & 65.78 & & 76.58 & \\
\hline & Heating & 88.41 & & 138.04 & \\
\hline & Transplanting & & 73.69 & & 104.15 \\
\hline & Transplant care & 5.68 & 112.30 & 6.96 & 166.77 \\
\hline \multirow[t]{3}{*}{ Grafting } & Manual grafting ${ }^{t}$ & & & & 180.29 \\
\hline & Grafting clips & & & 46.20 & \\
\hline & Miscellaneous supplies & & & 1.33 & \\
\hline Healing chamber ${ }^{\mathrm{s}}$ & Chamber supplies & & & 42.11 & 3.93 \\
\hline Total & & 321.04 & 187.36 & 794.20 & 458.08 \\
\hline \multicolumn{2}{|c|}{ Total (materials and labor) } & \multicolumn{2}{|c|}{1525.20} & \multicolumn{2}{|c|}{1252.28} \\
\hline \multicolumn{2}{|l|}{ Cost $(\$ /$ plant $)$} & \multicolumn{2}{|c|}{0.51} & \multicolumn{2}{|c|}{1.25} \\
\hline \multicolumn{2}{|c|}{ Selling price ( $50 \%$ mark-up) } & \multicolumn{2}{|c|}{0.76} & \multicolumn{2}{|c|}{1.88} \\
\hline
\end{tabular}

${ }^{2}$ Based on prices during budget development in Fall 2009.

${ }^{y}$ Based on average hourly agricultural wages (U.S. Department of Agriculture, 2009).

${ }^{x}$ Seed costs were calculated to reflect the total cost required for $20 \%$ oversowing and $90 \%$ grafting success (where applicable).

wInterspecific rootstock (De Ruiter Seeds, Bergschenhoek, The Netherlands).

'Determinate fresh-market variety (BHN Seed, Immokalee, FL).

uSeedlings were germinated by a local custom plug propagator (York, PA).

${ }^{t}$ Grafting rate was 100 plants $/ \mathrm{h}$ per worker and grafting wage was $\$ 14.00 / \mathrm{h}$. Grafting success rate was $90 \%$.

${ }^{\mathrm{s}}$ Once grafted, tomato transplants were placed in a healing chamber that holds 3300 plants for $7 \mathrm{~d}$.

respectively (Fig. 3). The majority of indirect costs of grafting were manifested as waste during the grafting procedure (Fig. 4C). These expenses could be reduced through innovative production techniques. Micrografting has been recently introduced into the arena of tomato grafting and this technique uses micropropagated scion grafted onto 3-week-old rootstock seedlings (Grigoriadis et al., 2005). For propagators unable to carryout this type of advanced procedure, similar principles of reducing indirect costs could be used.

LABOR COSTS OF GRAFTED TRANSPLANT PRODUCTION. Labor plays an important role in grafted and nongrafted transplant production budgets (Table 6) and contributes to the added cost of grafting directly and indirectly. In these case studies, manual grafting labor costs were $\$ 0.07$ to $\$ 0.18$ per plant (Tables 4 and 5). Using the same formula as in the PA sequence $[(\$ 16.39 / \mathrm{h})$ $\div$ (grafting rate $\times 90 \%$ success)] combined with current manual grafting rates (Kubota et al., 2008), the cost of the manual grafting procedure could be as low as $\$ 0.03$ to $\$ 0.06$ per plant.

Although the per-plant cost of manual grafting in our studies was relatively high, it did not increase the proportional labor costs of production in comparison with nongrafted plants. Interestingly, the proportional labor costs were lower in the grafted sequence in $\mathrm{NC}$ and similar in the PA study (Table 6). This effect is due to the additional material and seed costs associated with grafting in both of these studies (Tables 4 and 5). These results suggest that at current seed prices and under similar production methods, labor prices would have little or no effect on the feasibility of tomato grafting in U.S. transplant production systems compared with other factors such as rootstock seed and other indirect costs.

Although the price of labor in the United States may not have a strong proportional effect on the variable costs incurred for domestic production, the sheer volume of manual labor required for tomato grafting could be difficult to obtain. In the PA study, grafting wages were increased to $\$ 14 / \mathrm{h}$ to coincide with skilled labor wages. This may be one way to make labor more available for grafting. It could also be useful for propagators to market their clientele in a way that enables numerous moderately sized batches of grafted plants rather than attempting to produce one or several large batches in a given season.

COSTS OF ORGANIC TRANSPLANT PRODUCTION. At the NC location, the grower produced certified organic transplants for use on the farm while 
Table 6. Distribution of variable costs for tomato transplant production at Black River Organic Farm, Ivanhoe, NC (NC) and Good Harvest Farms, Strasburg, PA (PA).

\begin{tabular}{|c|c|c|c|c|c|}
\hline \multirow[b]{3}{*}{ Description } & & \multicolumn{2}{|c|}{$\mathrm{NC}$} & \multicolumn{2}{|l|}{ PA } \\
\hline & & Nongrafted & Grafted & Nongrafted & Grafted \\
\hline & & \multicolumn{2}{|c|}{ Variable costs (\%) } & \multicolumn{2}{|c|}{ Variable costs (\%) } \\
\hline \multirow[t]{3}{*}{ Seed $^{z}$} & Scion & 27.1 & 6.8 & 14.3 & 6.2 \\
\hline & Roostock & & 39.7 & & 19.4 \\
\hline & Total seed costs & 27.1 & 46.5 & 14.3 & 25.6 \\
\hline \multirow[t]{5}{*}{ Labor $^{y}$} & Transplanting & 16.3 & 7.4 & 14.8 & 8.6 \\
\hline & Transplant care & 12.5 & 2.8 & 14.5 & 13.3 \\
\hline & Manual grafting ${ }^{\mathrm{x}}$ & & 11.1 & & 14.4 \\
\hline & Chamber construction & & 1.4 & & 0.3 \\
\hline & Total labor costs & 28.8 & 22.7 & 36.9 & 36.6 \\
\hline \multirow[t]{8}{*}{ Materialsw $^{\mathrm{w}}$} & Plug costs ${ }^{v}$ & & & 11.3 & 10.0 \\
\hline & Heating costs & 24.1 & 5.4 & 17.4 & 11.0 \\
\hline & Potting mix & 11.9 & 5.1 & 6.0 & 3.0 \\
\hline & Plastic trays & 8.0 & 3.4 & 12.9 & 6.1 \\
\hline & Grafting clips & & 13.1 & & 3.7 \\
\hline & Grafting tools & & 0.3 & & 0.1 \\
\hline & Chamber materials & & 3.4 & & 3.4 \\
\hline & Total material costs & 44.0 & 30.8 & 48.8 & 37.8 \\
\hline
\end{tabular}

${ }^{z}$ Seed costs were calculated to reflect the total cost required for $20 \%$ oversowing and $90 \%$ grafting success (where applicable).

yBased on average hourly agricultural wages (U.S. Department of Agriculture, 2009).

${ }^{\mathrm{x}}$ Grafting speed was 200 and 100 plants/h per worker at the NC and PA locations, respectively. Grafting wages were $\$ 10.08 / \mathrm{h}$ in $\mathrm{NC}$ and $\$ 14.00 / \mathrm{h}$ in PA.

"Based on prices during budget development in Fall 2009 (see Tables 1 and 2 for details).

vSeedlings were germinated by a local custom plug propagator (York, PA).

the grower in PA did not. Interestingly, the introduction of organic certification into the NC production sequence made a negligible effect on the overall cost of transplant production. Management of a large-scale commercial organic transplant production facility may require added fixed and variable expenses that were not seen at Black River Organic Farm. In this example, the greenhouse was previously certified, and many of the variable expenses related to propagation were unaffected by organic certification (e.g., labor, heating, plastic materials). Exceptions to this include potting media, fertilizer, and certified or untreated seed. In this case, untreated seed was used and the cost of organic fertilizers was similar to those used in the PA study. Assuming the price of the "conventional" potting media used in the PA study (Table 2) in comparison with the price of the OMRI-listed potting media used for the NC study (Table 1), the additional soil costs associated with the organic potting media in the NC sequence added about $\$ 0.01$ to $\$ 0.02$ per transplant.

BENEFITS OF GRAFTED TRANSPLANT PRODUCTION IN THE
United States. At the NC location, plants were raised for on-farm tomato fruit production (Fig. 4A and 4B) and the benefit of grafted propagation translated to advantages associated with the utilization of the grafted plants. This grower had experienced repeated crop failures due to soilborne disease problems. The fruit production and economic benefits associated with the utilization of the grafted plants from this study have been provided in a recent report (O'Connell et al., 2009b). The deployment of resistant rootstocks to manage these diseases resulted in substantially higher per acre profit and ultimately allowed this grower to retain organic tomato fruit sales for retail and wholesale markets (O'Connell et al., 2009b).

The case study from PA provides a better perspective of how grafting may benefit specialized plant propagators that are interested in the production and sales of grafted plants. Grafting could provide a new niche for propagators to explore through retail and commercial sales, but the market will ultimately dictate the amount of profit recovered by their sale.

At the PA location, the grafted plants provided a more profitable use of greenhouse space to the transplant grower than the nongrafts. In this production sequence, heating costs were directly related to the amount of space needed for the crop (Table 2). For every $\$ 1.00$ the grower invested in greenhouse heating, nongrafted plants and grafted plants yielded $\$ 2.88$ and $\$ 4.54$ in wholesale mark-up, respectively (Table 5 ). Therefore, the grafted plants provided a more efficient use of greenhouse space. Although this trend would be similar regardless of the specific mark-up value (\%), it is reliant upon the assumption that mark-up of grafted and nongrafted plants is equal. Currently, there is little market supply of grafted transplants in the United States, but this new specialty market may help U.S. propagators retain profitability through wholesale and retail sales.

ECONOMIC MODELS AS A PRACTICAL TOOL. Models similar to the ones presented in Fig. 2A and 2B can be used to compare the cost of grafted plants at various production stages, and therefore serve as a tool to predict the cost of grafted transplants for a variety of fruit production systems. In the southeastern U.S., smaller transplants (three to five true leaf stage) are used for open-field production compared with the larger plants (six to 10 true leaf stage) used for tunnel production in the PA study. By omitting the 18-cell growth stage in the PA sequence, equivalently sized grafted plants (three to five leaf stage) at the PA location were $\$ 1.02$ while those at the NC location were $\$ 0.59$ per plant (Fig. 2A and $2 \mathrm{~B}$ ). The range of values $(\$ 0.59-1.02)$ seen in these case studies represent a fair estimate of transplant costs a grower might experience in the United States for production of a similar-sized, grafted transplant (about 6 weeks old), before mark-up.

This approach to illustrating costs of seedling production can also be used to identify areas along the transplant production sequence that could be considered for reducing the cost of grafting. For example, the discrete and continuous costs of grafted transplant production were twice that of the nongrafted plants before grafting and this can be visually observed in the PA sequence (Fig. 2B). Similar analyses of other production sequences may be used to determine areas where the additional costs of grafting could be 
addressed. Furthermore, such models could be adopted to help growers conceptualize profitable transplant production systems.

\section{Conclusions}

The case studies presented here are the first report of the variable costs of grafted transplant production in the United States and they represent two contrasting models of transplant production. Our results show that before mark-up, the utilization of grafting for tomato production could add $\$ 0.46$ to $\$ 0.74$ per plant, and including a $50 \%$ mark-up, this additional cost could be $\$ 1.12$ per plant. Our findings are generally higher than those found in Morocco (Besri, 2003), but are consistent with the estimated additional costs provided in a recent review (Kubota et al., 2008).

U.S. stakeholders are concerned about the high cost of labor and its relevance on grafting. However, it is important to note that many of the commercial propagation facilities using manual grafting worldwide are located in countries where labor prices are similar or only slightly less than in the United States. The average wages of Canadian agricultural field workers in 2003-08 ranged from \$10.85 to \$13.04 per hour (International Labor Office Department of Statistics, 2010) and other industrialized countries like Japan, Spain, and Italy currently produce grafted transplants without grafting robots (Besri, 2003, 2007; Kubota et al., 2008; Lee, 2003; Minuto and Causarano, 2008). In these case studies, we found that grafting labor costs made up a relatively small portion of the added cost of grafting, and labor costs were proportionally lower or similar among grafted plants as compared with nongrafted ones. These results do not suggest that the per plant cost of manual tomato grafting labor in the United States is negligible. However, they show strong evidence that labor prices in the United States may not be as important as previous speculations have suggested and that efforts to reduce the immediate cost of grafted plants may be better suited elsewhere. In both of these case studies, seed costs represented the highest additional cost of grafting and other factors such as grafting supplies and indirect costs played important roles in the additional cost of grating.
An important consideration for growers wishing to implement grafting for tomato fruit production is whether plants will be purchased or grown on the farm. In the PA case study, the per plant mark-up cost that a tomato fruit grower would pay was about $150 \%$ higher using grafted plants than nongrafted ones, and this factor could deter growers from buying grafted plants. Similarly, the initial expense of grafted transplants may reduce the likelihood of adoption in some growing systems, and our results showed that the total per plant increase in transplant cost ranged from $64 \%$ to $354 \%$. Clearly, further work that ascertains any economic benefits of grafting in tomato fruit production will be of value to growers in the United States.

The objectives of this study were not to design an optimum propagation system or to criticize current ones. Conversely, the goal was to explore two examples of successful grafted transplant propagation facilities and report their results. The specific cost a propagator may encounter is dependent not only on the level of care given, but also on environmental conditions at the facility and current seed and labor costs. In a similar way, the benefit of grafting for commercial propagators will ultimately be driven by market demand for grafted plants. Worldwide, grafting has been used particularly in greenhouses and high tunnels (Kubota et al., 2008; Lee, 1994), and preliminary reports suggest that tunnel growers in the United States would benefit from grafted plants (Groff, 2009a, 2009b; O'Connell et al., 2009a; Rivard et al., 2008b). The adoption of high tunnels in the United States (Carey et al., 2009) and the expansion of retail markets for grafted plants could be a valuable avenue for propagators looking to establish grafted transplant sales.

\section{Literature cited}

Besri, M. 2003. Tomato grafting as an alternative to methyl bromide in Morocco. 12 May 2010. <http://mbao.org/2003/ $012 \% 20$ besrimgrafting mbao $2003 \mathrm{sd}$. pdf $>$.

Besri, M. 2007. Current situation of tomato grafting as alternative to methyl bromide for tomato production in Morocco.
12 May 2010. <http://mbao.org/2007/ Proceedings/062BesriMGraftingSD07. pdf $>$.

Carey, E.E., L. Jett, W.J. Lamont, T.T. Nennich, M.D. Orzolek, and K.A. Williams. 2009 . Horticultural crop production in high tunnels in the United States: A snapshot. HortTechnology 19:37-43.

Freeman, J., S. Rideout, and A. Wimer. 2009. Performance of grafted tomato seedlings in open-field production. 12 May 2010. <http://mbao.org/2009/ Proceedings/045FreemanJGrafted $\% 20$ tomato\%20MBAO.pdf>.

Grigoriadis, I., I. Nianiou-Obeidat, and A.S. Tsaftaris. 2005. Shoot regeneration and micrografting of micropropagated hybrid tomatoes. J. Hort. Sci. Biotechnol. 80:183-186.

Groff, S. 2009a. Grafting in multi-bay high tunnels as a way to overcome soilborne diseases. 12 May 2010. <http://www. sare.org/MySare/ProjectReport.aspx?do= viewRept\&pn $=$ FNE08-636\&y $=2009 \& \mathrm{t}=\mathrm{l}>$.

Groff, S. 2009b. An economic comparison of grafted tomato transplant production and utilization in multi-bay high tunnels. 12 May 2010. <http://www.sare. org/MySare/ProjectReport.aspx?do= viewRept \&pn=FNE09-658\&y=2009 $\& \mathrm{t}=2>$.

International Labor Office Department of Statistics. 2010. ILO-LABORSTA database. 12 May 2010. <http://laborsta.ilo. org /STP/guest\#2193AA/>.

King, S.R., A.R. Davis, W.G. Liu, and A. Levi. 2008. Grafting for disease resistance. HortScience 43:1673-1676.

Kokalis-Burelle, N., E.N. Rosskopf, M. Bausher, G. McCollum, and C. Kubota. 2008. Alternative fumigants and grafting for tomato and double-cropped muskmelon production in Florida. 12 May 2010. <http://mbao.org/2008/Proceedings/ 063BurelleNMBAOAbstractoralpresenta tion2008Final.pdf>.

Kubota, C., M.A. McClure, N. KokalisBurelle, M.G. Bausher, and E.N. Rosskopf. 2008. Vegetable grafting: History, use, and current technology status in North America. HortScience 43:1664-1669.

Lee, J.M. 1994. Cultivation of grafted vegetables: Current status, grafting methods, and benefits. HortScience 29:235-239.

Lee, J.M. 2003. Advances in vegetable grafting. Chron. Horticult. 43:13-19.

Martin, F.N. 2003. Development of alternative strategies for management of soilborne pathogens currently controlled with methyl bromide. Annu. Rev. Phytopathol. 41:325-350. 
Minuto, A. and G. Causarano. 2008. The adoption of grafted plants in Italy: Highlights and critical aspects. 12 May 2010. <http://mbao.org/2008/Proceedings/ 127MinutoAandCausaranoG.pdf $>$.

Noling, J.W. and J.O. Becker. 1994. The challenge of research and extension to define and implement alternatives to methylbromide. J. Nematol. 26:573-586.

O'Connell, S., M.M. Peet, C.L. Rivard, F.J. Louws, and C.D. Harlow. 2009a. The grafted heirloom tomato system for organic production in high tunnels: Are there advantages in the absence of diseases? HortScience 44:1056. (Abstr.).

O'Connell, S., S. Hartmann, C.L. Rivard, M.M. Peet, and F.J. Louws. 2009b. Grafting tomatoes on disease resistant rootstocks for small-scale organic production. 12 May 2010. <http://ofrf.org/funded/highlights/ oconnell_07f30.html>.
Oda, M. 1999. Grafting of vegetables to improve greenhouse production. 12 May 2010. <http://www.agnet.org/library/eb/ $480 />$.

Rivard, C.L. and F.J. Louws. 2006. Grafting for disease resistance in heirloom tomatoes. 12 May 2010. <http://www4. ncsu.edu/ clrivard/TubeGrafting Technique.pdf $>$.

Rivard, C.L. and F.J. Louws. 2008. Grafting to manage soilborne diseases in heirloom tomato production. HortScience 43:2104-2111.

Rivard, C.L., F.J. Louws, M.M. Peet, and S. O'Connell. 2008b. High tunnels and grafting for disease management in organic tomato production. Phytopathology 98:S133. (Abstr.).

Rivard, C.L., F.J. Louws, S. O'Connell, and M.M. Peet. 2010. Grafting tomato with inter-specific rootstock provides effective management against diseases caused by $S$. rolfsii and southern rootknot nematodes. Plant Dis. 94:10151021 .

Rivard, C.L., S. O'Connell, M.M. Peet, and F.J. Louws. 2008a. Grafting as a viable tool to manage major tomato diseases in the southeastern USA. 12 May 2010. <http://mbao.org/2008/Proceedings/ 061LouwsFGraftingMBAO-08.pdf>.

Sydorovych, O., C.D. Safley, R.M. Welker, L.M. Ferguson, D.W. Monks, K. Jennings, J. Driver, and F.J. Louws. 2008. Economic evaluation of methyl bromide alternatives for the production of tomatoes in North Carolina. HortTechnology 18:705-713.

U.S. Department of Agriculture. 2009. USDA-NASS quick stats. 20 Dec. 2009. <http://www.nass.usda.gov/>. 